\title{
Underdevelopment, extractivism, and conflict in the Global South and the role of systemic alternatives
}

\author{
Subdesenvolvimento, extrativismo e conflito no Sul Global e o papel de alternativas sistêmicas
}

DOI: https://doi.org/10.22456/2178-8839. 113853

Barbara Magalhães Teixeira Departamento de Ciência Política, Universidade de Lund, Lund, Suécia barbara.magalhaes_teixeira@svet.lu.se

\begin{abstract}
A condition of underdevelopment has marked the nations of the Global South since the Second World War. The search for develop ment and for economic growth has made countries in the Global South dependent on global markets and international investment, and have made their environment and nature hostage to capitalist exploration. The process of development and of economic growth, coupled with the history of colonization and dependency present violent processes and structures that are source to conflict and instability all over the Global South. This article critically assesses the relationship between underdevelopment and the exploitation of the environment in the Global South and the violent outcomes that it reprodu ces. It finds that conflict and violence are inherent to the capitalist model of development, instead of anomalies to the system. Building from the field of critical development and decolonial studies, this article proposes ways to overcome dependency to extractivism by looking at the alternatives of anti-extractivism, degrowth and buen vivir to free both people and the planet.
\end{abstract}

Keywords: Development; Dependency; Environment; Extractvism; Global South;

\begin{abstract}
Uma condição de subdesenvolvimento tem marcado as nações do Sul Global desde a Segunda Guerra Mundial. A busca pelo desenvolvimento e pelo crescimento econômico tem tornado os países do Sul Global dependentes dos mercados globais e de investimentos internacionais, e tem feito o meio ambiente e a natureza de refém da exploração capitalista. O processo de desenvolvimento e de crescimento econômico, combinado com uma história de colonização e depedência apresentam processos e estruturas violentas que são fontes de conflitos e instabilitade no Sul Global. Este artigo analiza criticamente a relação entre subdesenvolvimento e exploração do meio-ambiente no Sul Global e os resultados violentos que eles reproduzem. O artigo aponta que conflito e violência são inerentes ao modelo capitalista de desenvolvimento, ao invés de anomalias do sistema. Construindo a partir do campo de estudos decoloniais e de desenvolvimento crítico, este artigo propõe estratégias para superar a dependência ao extrativismo ao olhar para as alternativas de anti-extrativismo, decrescimento e buen vivir, de forma a libertar tanto as pessoas quanto o planeta.
\end{abstract}

Palavras-chave: Desenvolvimento; Dependência; Meio-ambiente; Extrativismo; Sul Global; 


\section{Introduction}

Mainstream academic and policy accounts of the relations between underdevelopment and conflict in the Global South are usually organized into two ideas: the first is that underdevelopment stems from the inability of individual countries in harnessing the resources and the political will necessary to move towards development and industrialization. The second idea is that underdeveloped countries are trapped in a vicious conflict cycle (COLLIERet al., 2003) because of their failure to develop. It also connects the lack of development of poor countries to the ironic paradox of the resource curse: countries that are richest in natural resources are the ones presenting slower processes of development, and the biggest levels of inequality (COLLIER, 2007;SACHS, 2005).

Both of these assumptions that are widely shared in both academic and policy arenas come from a reductionist view of how development and conflict are produced and reproduced within countries, focusing too heavily on domestic and internal capacities of countries and forgetting to contextualize thelevel of development in the larger international and historical processes. This article aims at advancing a new model for the analysis of underdevelopment and conflict in the Global South that takes into consideration not only the internal characteristics of countries, but that alsolooks at the wider global process and patterns of capitalist expansion and exploitation of people and nature. Based on this, this article asks the question: how do we overcome the trap of underdevelopment and conflict in the Global South?

The article singles out the reliance on an exractivist model in order to advance development. Reliance on extractivism creates dependency on primary sector exports and puts countries of the Global South in the position of hostages of the fluctuations global economy and international markets. However, this is not an intrinsic characteristic of Global South countries, but they have been historically kept in this position of providers of raw materials and cheaper labor for the detriment of their own economic development and the accumulation of wealth in the North. In order to understand the relationship between underdevelopment and conflict, I argue that it is paramount to understand the structures of the global capitalist economies and how it purposedly keeps underdeveloped countries in this eternal search for development that never arrives.

This article aims at drawing the links between underdevelopment and conflict in the Global South as a whole and understanding them as larger patterns across the region, instead of singling them out as merelybeing products of internal characteristic of underdeveloped countries, which can become deterministic. The results of the theoretical analysis point to the need to overcome the extractivist model of development in order to reconcile underdevelopment and conflict in the Global South. A shift from the extractivistmodel, combined with other strategies to reorganize the economy, could liberate both people and the planet and allow for a more sustainable relationship.

\section{Underdevelopment and conflict in the Global South}

A mainstream economic approach views development as a linear and an unlimited process, or as has been argued, a process that can be divided into stages (ROSTOW, 1960). It understands that the process of development becomes natural once you combine industrialization, free markets, strong institutions and good governance. The combination of these internal and domestic policies would be the key why developed countries today have achieved this stage of development. Countries that are developing or underdeveloped lack these policies and internal institutions that allow for development, in addition to presenting high levels of corruption. This is mainstreamed by leading international institutions like the World Bank and the UN, which have asserted that corruption is the number one public enemy in the developing world, and that good governance is the most important factor in battling corruption, eradicating poverty, and promoting development (ROTHSTEIN; VARRAICH, 2017). The level of development is also seen to present a great indication for the risk of violent conflict and civil war: the lower the level of development the greater the risk for civil war 
(COLLIER, 2004). In this sense, policies aimed at elevating development levels based on increase in economic growth are seen as strategies to break the vicious cycle of poverty and armed conflict in low -income countries (COLLIERet al., 2003).

However, critical analyses of the process of development and economic growth would question the linear and automatic view of these processes, and would argue that they are actually violent in and of themselves. Patterns of development are very different for former colonial powers and former colonized nations, for example, and this has reverberations until today. In the colonial period, Western European powers appropriated huge amounts from the Global South through slavery, forced labor and dispossession - which all generated wealth for free. The resources and the free labor they extracted from the colonies allowed them to power their industrialization and development, and "Europe's development couldn't have happened without colonial loot" (HICKEL, 2017). In this sense, development for European colonial powers meant underdevelopment for the colonized nations, and as RODNEY (1972) argues, underdevelopment should not be seen as a product of internal and domestic factors of Third World societies, but as a consequence of the integration of former colonies into the world system, in the process of capitalist expansion. This proces s had permanently and violently changed and restructured thelocal economies of colonized nations and put them in the condition of pursuing economic growth determined by foreign capital and foreign markets rather than by local needs (STAVRIANOS, 1981).

The ideology of development based on economic growth requires that central capital expand its extraction geographically in order to realize surplus-value, and in the periphery this is done through the destruction of economic and social organizations and through military coercion (LUXEMBURG, 1913). In this sense, it is an illusion to think that countries of the South that are in the position of dependency to resource extraction and export could everbe able to 'catch up' to higher levels of development, because they themselves serve the fundamental role in the structure of the global economy of being exploited for cheaplabor and resources.

In this sense, Rodney (1972) argues that development cannot be seen merelyas an economic process, but it has to be understood through how it ideologically structures societies, because of all its political implications. This is why the ideology of development for the Global South can be seen as a utopian horizon (PRADO, 2020). First, it is a horizon because it is seen as a goal, a target, the objective of finally becoming developed; second, it is ut opian because it never arrives. Countries in the Global South have been chasing development since they were branded as "underdeveloped" and have used every strategy, rule, and plan recommended (or imposed) by the North and still have not achieved this utopian destination. However, development is not only a horizon and an objective in itself, it is also a process and a project. As Prado (2020, p. 57) put it, development "is normally identified a priori with a specific historical process and with a determined political project, and both as a process and as a project they appear framed, implicitly or explicitly,in the mid st of the capitalist system, which is how it is naturalized”. And the narrative of development empties it from any historical process, and takes the model of development tied to economic growth and capital investment as naturally given, which means that development is assumed singular, particular and universal all at once.

The shift from the use of Third World to Global South to indicate underdeveloped, less developed, or developing nations also indicates a process of emptying the political and historical process that characterizes the creation of this bloc and their struggle. The same way that 'corruption' became 'bad governance', so did Third World become Global South because it is a more palatable term. The shift also comes with "the immense relocation of production from the First World to the Third World, thus allowing corporations to take advantage of wage differentials and of significantly fewer restrictions on environmental and labour standards" (SAJED, 2020). Thus, the emergence of the Global South is connected to the rise of neoliberalism and the new geography of production, marked by austerity measures, decrease of state investment, soaring rates of unemployment and wage disparities, and financialization of the global economy. Development fulfills its role as an ideology also because it is created by the dominant powers with theintention of keeping the status quo: Global North as developed and Global South as underdeveloped. The rich nations of the North have imposed the idea of development and economic growth to the undeveloped nations of the South both as an strategy and as a utopian 
horizon, in this way making it tautological: in order to develop you need development, and you get development because you develop (PRADO, 2020). This ensures that countries of the Global South and of the periphery of the world never reach this horizon of development: the rich nations need to keep poor nations in this carrousel to maintain their position as providers of raw materials and cheap labor.

Indeed, since colonial times, the countries in the Global South have served as the providers of cheap labor and cheap nature for production and consumption of the countries of the North (HICKEL et al., 2021). This is also the source of a lot of conflicts. Research has shown that it is not only the level of development that affects the risk of civil war, but it is the dependency of developing countries in primary exports like oil and minerals that can affect their political stability (COLLIER; HOEFFLER, 2000; FEARON, 2005). This is because it leads to the development of a rentist of overreliance on rents from the extraction, rise of authoritarianism and a negligence towards the population, and increasing inequality (HUMPHREYS, 2005; ROSS, 2004a; b). Not only that, the Global South is also the site of more than 83 percent of the world's industrial workforce (SMITH, 2016, p. 102). The puzzle lies in the fact that even though these countries host the largest share of industrial activity, and also bear the environmental costs from it, they do not benefit from the value that they produce - is it rather appropriated through financial flows by multinational companies and other trade obstacles.

While the development narrative claims that the rich nations of the world would transfer their technological skills and knowledge to poor countries in the Global South, in reality, the so-called 'development cooperation' is marked by much larger amounts flowing from the South to the North than otherwise (DORNINGERet al., 2021). This geopolitical and monopoly power that Global North countries and corporations have on setting different price for labor and nature in the South is what enables unequal exchange and appropriation of value from the South by the North. This sustains high levels of income and of consumption in countries of the Global North, while depressing the trade revenuesin the South, "denying them access to resources that could be used for investment in public services, economic development and poverty reduction" (HICKEL et al., 2021). All of this would allow countries in the Global South to better deal with social conflicts, as well as mitigating the chances of civil war occurrence.

Recent empirical research confirms that there is an immense disparity between the value that countries of the Global South produce and input into the global economy, and the amount that is appropriated from them by the Global North. The Global Financial Integrity (GFI) and partner organizations reported that developing nations are actually netcreditors to the rest of the world, in a twist to the development narrative. In the most comprehensive assessment of financial flows between countries of the Global North and the Global South, the report shows that in 2012 developing countries received around $\$ 2$ trillion on aid, investment, and income from abroad. In the sameyear, it recorded that almost $\$ 5$ trillion flew out of the Global South - more than twice the amount. This means that Global South countries were in credit of almost $\$ 3$ trillion in a single year. Since 1980, the net outflows total \$26.5 trillion dollars (GLOBAL FINANCIAL INTEGRITY et al., 2015). This means that the argument for capital investment and foreign aid to developing countries as strategy to eradicate poverty and promote development is not conducive with the real direction of financial flows. It also does not support the claim that corruption is the biggest enemy of development in the South: GFI estimates that only $3 \%$ of total financial flows - between $\$ 20$ and $\$ 40$ billion - account for 'open' corruption which is often portrayed as the reason for underdevelopment in the Global South. This disconnect between policy narrative and reality might be because of a culture of methodological nationalism that analyzes these issues as domestic factors of isolated countries, instead of also looking at unequal relationships between countries that are produced and reproduced by the structures of the gl obal economy (HICKEL et al., 2021).

By far, the largest numbers of outflows are connected to illicit financial flows, and most of them tied to the extractive industries (MURPHY, 2012). GFI reports that developing countries lose around \$973 billion each year in capital flight, plus $\$ 1,750$ in trade misinvoicing. Indeed, a large sum of illicit financial flows are transferred into off-shore accounts and tax havens, which hampers the possibility of these revenues being taxed and being used for social spending in 
developing countries. In 2011, GFI estimates that tax haven holdings of total wealth from developing countries was valued at \$4.4 trillion dollars. And the big difficulty in discussing, measuring, and fighting illicit financial flows is that these activities fall under the 'illicit' category and not the 'illegal' one. MURPHY (2012) argues that this is specifically because of loopholes intentionally left in the laws of Global North countries on how to deal with taxing and movement of profits of multinational corporations.

In this context, the most affected are developing countries because of the loss of comprehensive amounts of revenues that should be taxed and could be used for social spending. The GFI argues that significant and persistent unrecorded financial flows hamper developing countries' capacities for growth and economic development, and has real impact in people's lives and living standards, as well as countries' political stability. And this is because "the institutions that enable significant illicit activity to persist in a particular country redirect productive resources away from those economic activities designed to improve living standards and reduce inequality for the countries' citizens" (GLOBAL FINANCIAL INTEGRITY et al., 2015). Based on this discussion, I understand underdevelopmentin the South as being a by product of development in the North, and this is true from the colonial era until today. The structures of the capitalist global economy allow for the accumulation of wealth and resources by countries and elites of the North, while reproducing inequality and injustice in the South. It is only through a holistic approach to the relationship between capitalist expansion and the structure of the global economy that it is possible to understand that problems of underdevelopmentin nations of the Global South are not intrinsic to internal and domestic factors, but are interacted with the structures that produce and reproduce inequality globally.

This not only affects the level of development of countries in the Global South, but it also interacts with the risk of violent conflict. The unequal patterns of international trade that reproduce economic and political inequality also hamper socio-environmental sustainability. The concept of 'burden-shifting' takes place when countries of the core of the global system shift the environmental and social costs of high industrial activity and resource extraction to poorer nations, while benefitting from the financial and material accumulation (DORNINGER et al., 2021). This displacement of 'extractive frontiers' from the core to the periphery is linked to the rise of environmental conflicts that affect mainly indigenous and peasant communities in the Global South (TEMPER et al., 2015). A report from GLOBAL WITNESS (2020) shows that land and environmental defenders that act to protect the environment from both extractivism and climate breakdown are the most affected by these types of conflict. Between 2012 and 2019 there were at least 1,946 environmental and land defenders killed around the world, most of them occurring in countries like Brazil, the Philippines, Colombia, Honduras, Mexico and Peru. Indigenous people are the ones most at risk, accounting for about a third of all the killings, which are mostly associated with mining, agro-industrial, and logging projects. Research shows that the determinants that explain the occurrence of these killings include income level, foreign direct investment, mineral dependence, and regime type (LE BILLON; LUJALA, 2020).

Dependency in primary sector is also a common explanation for the occurrence of civil war. States thatrelyon the export of primary commodities (COLLIER; HOEFFLER, 2000), especially oil (FEARON, 2005; FEARON; LAITIN, 2003) present an increased risk for civil war. This is because the presence of abundance of natural resources like oil and minerals creative incentives for investment in the primary and export sectors, development of a rentist mentality, rise of authoritarianism and inequality (HUMPHREYS, 2005; ROSS, 2004a; b). Data for internal armed conflicts since 1989 also shows that all civil wars related to natural resources are located in countries of the Global South. This is true for all civil wars connected to natural resources through distribution, financing, or aggravation from climate change. Indeed, climate change and environmental breakdown are increasingly being pointed as important sources of instability and insecurity for countries and communities of the Global South (IPCC, 2001; KOUBI, 2019). In light of this, there has been an upsurge in scholarship and policy calling for the need to address issues of both conflict and environmental concerns, focusing on 
improving governance of natural resources to avoid that issues such as corruption and inefficiency can play a role (BRUCH et al., 2016).

However, focusing on resource governance falls again into the trap of looking only at the domestic characteristic of countries in the Global South instead of connecting it to the larger structures of the global economy. It seems impossible to analyze abundance of natural resources like oil and minerals in countries of the Global South without connecting it to the global scarcity of these commodities that are key to the functioning of the global economy. It is also a reductionist approach to see issues of dependency as only internal to these countries, without taking into consideration the historical processes that have solidified the position of the countries of the Global South as providers of raw materials for industrial activity in the North. Over the course of four centuries, and rooted in colonial domination, the extraction and export of primary commodities has relegated countries of the Global South to the periphery of the system, based on the global division of labor. In this sense, we can connect both the creation of underdevelopment and of the dependence on extraction of primary commodities to the historical process of capitalist expansion. We can then understand how countries of the Global South are put into this carrousel of searching for development through the growth of the extractive sector, increasing dependency and in turn, conflict and underdevelopment. In order to address both conflict and underdevelopment in the Global South, it is necessary to tackle the structures of extraction, which produce and reproduce them.

\section{Methodology}

This article is based on a historical materialist analysis (HALLIDAY, 1994) of the process of development, dependency and conflict in countries of the Global South as a whole, tracing the structures of extractivism that organizes these processes. Theoretically, this article is informed by critical development (RODNEY,1972) and decolonial studies, as well as geography (HARVEY, 2005) and political ecology (PELUSO; WATTS, 2001). In line with these approaches, and based on the discussion so far, I view development as inherently conflict-laden and a violent process towards both people and nature. The analysis follows a qualitative approach required to understand the multiscalar processes and relations between underdevelopment and conflict in the Global South, with a focus on extractivism in Latin America and Africa. A number of illustrative cases across Latin America and Africa are chosen to avoid falling into the trap of methodological nationalism (HICKEL et al., 2021) and only looking at processes and characteristics inside one country in order to understand this relationship. Instead, by looking at different cases across two regions we skip attributing the effect of underdevelopment and conflict on individual and cultural characteristics of specific countries, and are able to draw larger conclusions about wider patterns of processes across the Global South.

\section{The extractivist model of development in Africa and Latin America}

Even though research has shown the link between extractivism and both conflict and underdevelopment (JOHNSON, 2017; RESTREPO BOTERO; PEÑA GALEANO, 2017; TEMPER et al., 2015), many countries in the Global South still rely on this strategy to promote 'development'. A focus on the extractive industry in Africa is argued to help jump -start economies after armed conflict. Coupled with resource governance, it should be able to advance both peace and sustainable development (BRUCH et al., 2016). In Latin America, leftist governments across the continent that formed the Pink Tide promoted the intensification of export-oriented and resource-intensive economies, with means to finance social services. However, the structures that keep underdevelopment and dependency in place are extremely difficult to move, and institutional and domestic fixes that focus on the intensification of extractivism are more likely to strengthen the position of these countries of the Global South as the periphery of the global economy and the occurrence of conflict. 
Here, extractivism is understood as both the intensive and extensive exploitation of natural resources that has historically marked countries and nations of the Global South as providers of raw materials, as well as the political and economic effects that is reproduces like little to no industrialization, export as principal destination, intensive extraction that impedes natural renovation, economic dependency on primary commodities, rentist and clientelist structures, authoritarian governments and policies, underdevelopment, and socioenvironmental conflicts (ACOSTA 2016; RIOFRANCOS, 2020). In this way, the practice of extractivism is built on both the exploration of natural resources and nature, but also on the labor and livelihoods of marginalized communities in the Global South.

So the extractivist model has much larger negative effects in the structures of the economy and of national governments than positive effects for development and human wellbeing. It can be seen as a paradox that the countries that are actually richest in natural resources are also the poorest in economic standards. This can be attributed to the dependency of middle and low-income countries' economies in the extractive sector and the export of primary commodities in the extractivist model of development. Data from the International Council of Mining \& Metals' report on the role of mining in national economies shows that 45 out of 50 countries that score highest in the Mining Contribution Index are from the Global South, and most of them are classified as lower - or lower-middle income countries (ICMM, 2016). The report also shows that many of the countries dependent on mineral resources exploration and exports continue to become even more dependent through time. Between 1996 and 2012, almost all lower-income countries saw increases in the export dependence ratios, with increases as high as 94\% in Chad and 76\% in Sudan (ROE; DODD, 2017). This means that these countries are highlyvulnerable to volatile prices of commodities in the global market, and shifts in prices could have detrimental effects to the countries' economies but also to their political stability. In Colombia, a rise in the price of oil between 1998-2005 of 137\% was connected to an increase of $14 \%$ in paramilitary attacks in oil -producing municipalities (DUBE; VARGAS, 2013). The end of the commodities boom in 2012 also gave way to rise in authoritarianis $m$ in South America, culminating in the coup against Dilma Roussef in Brazil in 2016 (ACOSTA, 2016).

As of 2016, there are over 101 British companies with mining operations in sub-Saharan Africa, controlling over 1.05 trillion dollars' worth of resources. Of these companies, 25 are incorporated in tax havens (CURTIS, 2016). Murphy (2012) argues that there is a high risk of transfer mispricing to go undetected within extractive industries and this has a big impact on developing countries since the extractive sector represents such a large share of their economies. The economic power that transnational companies have in developing countries translates into political power because the amount of their contribution to the national economy is too big. This makes countries hostages to these companies because they permanently threaten the governments that dare to increase taxes, review and rewrite contracts, and impose legislations that regulate their actions (ACOSTA, 2016). In the case of Zambia, the government has been trying to fix legislation on the rate of royalties from mineral extraction, but a lot of the agreements for mineral development between the government and multinational corporations have stability clauses exempting these agreements of any changes in tax law for up to 20 years. In the case of Liberia, an agreement between Arcelor Mittal and the government indicated that it was the company the responsible to set the price of the iron ore and therefore the basis of the royalty rates as well (MURPHY, 2012).

In part this can be attributed to corruption and the private relationships between owners and executives of these companies and government officials. But these transnational companies have infinite resources and power to negotiate and to pressure governments of developing countries to make all sorts of concessions that would otherwise be important for their development. This happens because governments have no bargaining power when facing transnational companies, specifically because they are forced to compete with other commodity exporter countries to drive down prices and taxes in order to attract foreign investment (HICKEL, 2017). And the dependency of Global South countries in their extractive and export sectors has consequences to their political stability. In Latin America, for example, where processes of extraction are particularly charged, the designation of the extractive sector as 'strategic' for the economy because it is a 
key source of fiscal revenue justifies the use of force by the state to protect extractive projects (RIOFRANCOS, 2020). This is also true especially when international corporations are involved. Research shows that in regions of Sub-Saharan Africa where transnational companies have the ownership of exploration of oil, there is an increase of the use of state repression as an answer to societal dissent (WEGENAST; SCHNEIDER, 2017). The power of transnational corporations in the extractive sector creates also a complex process of 'deterritorialization' in which the state is relatively unaware of actions of these companies inside mining and extractive enclaves. A lot of the times the state reallocates to these companies the responsibility to attend to social demands, which gives them even more power relative to the government and makes it more difficult to implement national legislation and accountancy mechanisms. ACOSTA (2016, p. 60) argues that this "consolidates an environment of generalized violence, rising poverty and marginalization that flows into short -sighted responses and a police state that does not comply with its social and economic obligations".

In both Liberia and Sierra Leone, in the post-conflictcontext, the attempt of the national government to reactivate the extractive industries to jump-start the economy towards development instead escalated tensions between multinational corporations and local communities. This is due to the government ceding around 82 percent of land in those countries to multinational companies and intensifying longstanding land ownership disputes that have been present since colonial times. This also affects issues regarding environmental degradation, impacts on the communities' livelihoods, and violation of human rights (BEEVERS, 2019; BROWN et al., 2012; JOHNSON, 2017). As discussed before, transnational corporations are often responsible for large number of outflows coming from extracting countries of the Global South to the Global North (GFI, 2015). While intensifying the extractive sector might be able to increase the amount of production and of revenues produced, the majority would flow out to countries of the North or to tax havens, leaving countries of the South without the ability to increase the fiscal revenues.

On top of that, the extractive industry is capital intensive rather than labor intensive, which means that it is uncapable of absorbing locallabor force, andit is also marked by an unequal distribution of revenues and assets. Extractive industries are capital intensive and focused on exports, and the small number of jobs that they produce are highly skilled and coming from abroad. The technology used in these industries is also almost all from abroad, which diminishes the amount of domestic value generated by this industry. As a consequence, "extractive activities promote clientelist social relations that benefit the interest of transnational companies and that prevent the implementation of local and national development plans" (ACOSTA 2016, p. 61). In the end, while intensifying the extractive industries is seen to promote development and generate more revenues, it actually intensifies the isolation and dependency of commodity-exporting economies, increasing the risk of conflict and underdevelopment in a cyclical process.

This phenomenon is also observed in Latin America. The leftist governments that took power throughout the continent during the Pink Tide around 2009 argued that in order to break from dependency and create real development the extractive industry should be marked by a national ownership of oil and minerals, and that the revenues should be used to finance public services. In the specific case of Bolivia and Ecuador, the governments of Evo Morales and Rafael Correa, respectively, adopted theidea of buen vivir as an alternative to the capitalist and imperialist modes of development that rendered Latin America underdeveloped and dependent. Buen vivir is a concept coming from the indigenous cosmovisions of sumackawsay and suma qamaña from the Aymara and Quechua peoplesfrom the Andes (SOLÓN, 2019). In its most practical understanding, buen viviris "postulated as an alternative to capitalistic development that mustbe based on a new relationship with nature and the search for an economic model that does not plunder nature's resources" (RESTREPO BOTERO; PEÑA GALEANO, 2017, p. 272). However, the discourse of both presidents in particular, and of further leftist governments of Latin America, has generated major debate because it is believed that these are merely rhetorical changes and do not translate into real transformation in state policies. The anti-imperialist and anti-capitalist rhetoric promoted by these governments when adopting buen vivir visions contrast with many policiesin favor of building a modern society, increasing productivity and industrialization, and strengthening the role of the state as a promoter of 
development (SOLÓN, 2019). At the height of the Pink Tide, there was not only a proliferation of counter-hegemonic processes in governments and in the streets, but there was also a paradoxical intensification of "an export-oriented, resource-intensive model of accumulation, highly dependent on foreign capital” (RIOFRANCOS, 2020, p. 5).

However, a pattern that can be observed across the region in Latin America is that even though leftist governments are capturing more revenues from resource extraction, they are also becoming more dependent on exportation of raw materials, while the industry and agricultural sectors have weakened against the extractive sector interests (RESTREPO BOTERO; PEÑA GALEANO, 2017). This means that even though the lives of millions of citizens have improved under socioeconomic indicators, the countries remain in a position of subjugation in the international division of labor, exporting mainly low value-added products. And improvements in human development coexist with persistence of structures of informal work, inequality in land tenure, and increasing concentration of capital in some sectors of the economy. This means that in order to attend to social needs, the progressive governments of Latin America relied increasingly more on resource rents instead of promoting deeper transformations in class relations - "solong as there was an influx of oil rents, the income of the poor could be increased without expropriating the wealth of the rich". This created a dynamic of 'redistribution without structural change', which marked the continued "reliance on a primary-export model of accumulation that generated these persistent forms of precarity, inequality, and the concentration of wealth" (RIOFRANCOS, 2020, p.10-11).

The biggest challenge of leftist and progressive governments when taking power in Latin America was the rush of presenting immediate results in social programs, and the fastest way to finance this was by intensifying extractivism. This not only led to the increase of dependency on extraction and export of natural resources, but it also increasingly affected indigenous and peasant communities in the form of violence, displacement, and environmental degradation. Even though there were some changes to resource governance, like for example in land tenure which benefittedindigenous and peasant communities, the history of market reforms during the neoliberal era continued to affect the guidelines for state intervention and corporate investment in the resource sector. The legacy of deregulation of resource markets, invasion and sale of land for exploration and extraction for low prices and insufficient legal, environmental, and labor supervision continue to mark the extractive sector in these countries, allowing for the continuation of the power of foreign investors over national policies (RIOFRANCOS, 2020).

The governments of Rafael Correa in Ecuador, and Evo Morales in Bolivia attempted toinstitutionalize buen vivir without rupturing with the accumulation of extractivism, thus showing the friction between ancestral and decolonial ideas and the lack of space for change in the current developmental and capitalist system (BITTENCOURT, 2017). Instead of promoting systemic change to reorganize public spending, they have relied on growing extraction and production in order to finance redistributive social policies. However, this dependence on extractivism has clashed with the aim of protecting the environment, and conflicts continue to rise between local communities and the government (SVAMPA, 2016). The negotiation of extractive interests can "keep traditional national elites in a comfortable position of economic power while compromising national autonomy due to the economy's overreliance on commodity exports" (FERNANDES, 2020, p. 141). In this sense, the environment continues to be exploited without limits, and social conflicts and inequality continue to be a common feature of this system.

\section{Alternatives to development and extractivism}

In an age of ecological limits, the increasing dependency of Global South countries in the extractive sector puts them in an impossible position of having to choose between deepening extractivism and improving socioeconomic indicators to the larger population on the one hand, or protecting the environment on the other. A lot of pressure is put on the countries of the Global South by the international community and especially developed countries of the Global North to protect the environment and to slow down deforestation. At the same time, these countries are forced to increase 
extraction of natural resources to supply not only their growing population's needs, but also to sustain high consumption and development levels in the North. Countries of the Global North are responsible for $92 \%$ of global excess carbon emissions that are responsible for climate change. This means that countries of the Global South, including emerging economies like the BRICs, are responsible for $8 \%$ of those emissions (HICKEL, 2020). This is because, even though countries of the Global South are the site of extraction and industrial activity, they are not the consumers of these industries, but bear the social, economic, and environmental consequences of extractivism. All of this is done, or justified, under the pursuit of 'development'. First, in the North, and now in the South, the pursuit of development through economic growth, extractivism, and subjugation of nature has not only maintained underdevelopment, but it has also depleted the environment and exacerbated socioenvironmental conflicts.

The idea of anti-extractivism has emerged as a movement to provide alternatives to the capitalist and extractivist model of development, while protecting the environment and increasing wellbeing. It not only criticizes the capitalist and imperialist model of developmentimposed in countries of the Global South, but it also entirelyrejects extraction itself, and proposes a post-extractive society. Anti-extractivism identifies that not only is dependency and imperialism the cause of underdevelopment and social conflicts, but it is the ideology of infinite extraction of resources that serves as foundation for exploitation and colonization of both people and nature. In this sense, to break with notions of underdevelopment, of exploitation, and to achieve harmony between humans and nature, it is necessary to break with the ideology of development based on economic growth and resource extraction. As the former mayor of Cochabamba, Bolivia putsit: "we denounce to the whole world the mistreatment of Mother Earth by developed countries, but we reserve ourselves the necessity of also mistreating Mother Earth for a while until we arrive at a minimum level of development” (PUENTE, 2011). It is not possible to achieve a 'good enough' level of development to the entire population of the world within ecological and planetary boundaries without rupturing with capitalistmodes of production and extraction. It is necessary to rupture with the roots of violent exploitation if we are to protect both people and nature.

As discussed before, the ideology of development puts countries of the Global South and the periphery of the world in this condition of pursuing eternal economic growth, while natural resources are finite. This allows for the continuation of underdevelopment and the intensification of environmental breakdown in the South, while maintaining high levels of consumption in the North. Research shows that from a certain level of GDP, increase in economic growth does not translate into improvements in quality of life (PETRIDIS et al., 2015). Instead, research shows that even though there are currently no countries that achieve high levels of social outcomes for their populations within planetary boundaries, countries of the Global South are the most effective at it (O'NEILL et al., 2018). Countries like Vietnam, Cuba, Jordan, and Costa Rica are examples of countries that perform well in social indicators like employment, healthy life expectancy, and nutrition, while transgressing few biophysical boundaries (GOOD LIFE FOR ALL PROJECT, 2018). Countries of the Global South are also the best ranked in the Sustainable Development Index, which takes into consideration how resource efficient countries are in achieving human development within planetary boundaries (SDI, 2019). These results show that it is possible to break away from the ideologies of development, economic growth, and extractivism while providing both physical and social needs to entire populations while protecting the environment. Indeed, researchers show that based on the amount of resources that have been historically extracted and transformed industrially, and the amount of value generated in this process, it is possible to provide 'a good life' for the entire global population within planetary boundaries (O’NEILL et al., 2018).

In this way, in order to overcome both underdevelopment and conflict in the Global South, the strategy should not focus on intensifying extractivism in order to generate more revenues, but should rely on processes of redistribution of resources and reconfigurations of class relations in order to provide a good life for all while attending to ecological limits. In order to do this, it is necessary to replace the ideology of development and of extractivism with differentunderstandings of the relationship between humans and nature. This can be found in the epistemology of buen vivir, for example, but also 
in other cosmovisions around the world like ubuntu (SOLÓN, 2019), ujamma (BITTENCOURT, 2017), and swaraj (KOTHARI et al.,2014). In this way, these understandings cannot be applied to existing structures and process like a list of policies to be followed. They are rather a systemic al ternative with the potential to completely rearrange social, class, and environmental relations, and to move the goal of our societies away from the exploration of people and the environment and into coexistence.

One of the most violent ways that theideology of development has reigned over communities of the Global South, is by homogenizing different cultures and ways of seeing the world. In order to promote the American way of life based on capitalist overconsumption as 'ideal', it was necessary to erase entire ways of life of indigenous and traditional communities in the Global South, and to brand them as retrograde and backwards (LANG, 2016). The ideology of development was sold to nations of the Global South that they should abandon their traditional ways and culturesin order to join the homogenized and globalized society. The strength of systemic alternatives that are based on different epistemologies from the South is that they provide not only a different way into seeing the relationship between development and underdevelopment, and between humans and nature, but because they provide a number of different ways of understanding the world and our relationship to it. This means that there is space to build alternatives to both extractivism and capitalist development, and to create different societies where nature and humans are valued kindlier. The experiences of Ecuador and Bolivia in institutionalizing buen vivir without breaking with the structures of capitalist modes of production and exploitation shows two important things for thinking the emancipation of the Global South in an age of ecological limits. First, systemic alternatives become an interesting and viable alternativenot when they are imposed from the top-down, but when they are brought up by social movements and community organizations. SOLÓN (2019) argues that a key mistake committed by these governments was to believe that buen vivir could be implemented as a national state plan, when it is rather a new societal reality that should be built at the grassroots level. The focus should be not in centralizing the alternatives in the hands of the state which is still very constrained by transnational companies, trade obstacles, and the structures of the global economy. Instead, the local level where community relations and organizations can act to create new cultures and strategies for social and structural change should be potentialized. Indigenous, peasant, and other marginalized groups have been resisting the ideology of development and of extractivism for centuries (KRENAK, 2020). In this context, their struggles should not only serve as examples of the work that is needed ahead, but their strategies and knowledge should be amplified.

Second, it has proven impossible to create and implement systemic al ternatives at large scales that are isolated at the national level. The attemptto institutionalize buen vivir only inside the borders of both Bolivia and Ecuador have shown how these countries were restrained by both national characteristics, but especially by the structures of the global economy. In order to create a viable alternative, it is necessary to create articulations between different processes across the world. However, this articulation is not only between processes of emancipation in the South through alternatives like ubuntu, ujamaa, and swaraj mentioned before. It is imperative that these processes of social transformation expand themselves beyond the national and regional borders of the Global South and into the center of countries that today colonize the planet in different ways. This is why the articulation of buen vivirfor example should be connected to strategies of degrowth in highly industrialized countries of the Global North. Degrowth strategies focus on decreasing resource and energy use by countries and communities in the Global North, as well as moving away from economic growth and capital accumulation as the center of our societies (KALLIS, 2018). By confronting the problem of overconsumption and accumulation at the source of global power through degrowth, it is possible to allow room and space for nations of the Global South to reorganize their societies away from pursuing development and extractivism and to overcome dependency and underdevelopment while attending to ecological limits. 


\section{Conclusion}

This article has critically analyzed the relationship between underdevelopment, extractivism and conflict in the Global South. By having a critical and decolonial approach to the progress of the ideology of development based on economic growth and resource extraction across the Global South, it is possible to argue that the same structures that promote high development levels in the Global North are the ones promoting underdevelopment in the South. Since colonial times, nations of the Global South have been put in the condition of supplying raw materials and cheap labor to the accumulation of capital and the development of nations of the Global North. This has created a long process of dependency on the export of primary commodities and on the extractive sector, which keeps nations of the Global South underdeveloped.

The eternal pursuit of development based on intensification of extractivism and dependency has made countries of the Global South volatile to changes in the global market. This has consequences not only for their economies, but also to their political stability. In this article, I identify that underdevelopment, dependency, and conflict all share the simil ar root cause in extractivism. The nationalization of resources and of companies does not rupture with the violent and unequal structures of growth and exploitation. The wave of neo-extractivism by progressive governments in Latin America shows that changes in nationalization of resources and statization of extractive companies in order to only increase redistributive policies does not put into balance the relationship between underdevelopment, extractivism, and conflict. This is why I argue that extractivism should not be seen as a tool for promoting development in post-conflict countries. Instead of providing opportunities for these countries of breaking out of a conflict cycle, intensifying extractivism would further reproduce inequalities and increase risk for violent conflict. In order to overcome the trap of underdevelopment and conflict in the Global South, it is necessary to completely break away from the extractivist model of development that has marked countries of this part of the world since colonial times. Alternatives to both development and extractivism are rooted in community and social organizations in the periphery of the Global South that have resisted colonization for centuries. Ideas like buen vivir, ubuntu, ujamaa, swaraj, coupled with strategies for degrowth would enable for the emancipation of countries of the Global South and provide a good life for all across the world while attending for ecological limits.

\section{References}

ACOSTA, A. Extrativismo e neoextrativismo: Duas faces da mesma maldição. In: DILGER, G.;LANG, M., et al (Ed.). Descolonizar o imaginário: Debates sobre pós-extrativismo e alternativas ao desenvolvimento. São Paulo: Autonomia Literária \& Editora Elefante, 2016.

BEEVERS, M. D. Peacebuilding and Natural Resource Governance After Armed Conflict. Palgrave Macmillan, 2019.

BITTENCOURT, R. Para além do desenvolvimento ocidental: ancestralidades na descolonização dos projetos políticos de Bolívia, Butão, Equador e Tanzânia. 2017. (Master of Social Science) - International Relations, PUC Minas, Belo Horizonte.

BROWN, O.; HAUPTFLEISCH, M.; JALLOW, H.;TARR, P. Environmental Assessment as a Tool for Peacebuilding and Development: Initial Lessons from Capacity Building in Sierra Leone. In:JENSEN, D. e LONERGAN, S. (Ed.). Assessing and Restoring Natural Resources in Post-Conflict Peacebuilding. Oxon, UK: Earthscan, 2012

BRUCH, C.; MUFFETT, C.; NICHOLS, S. S. Natural resources and post-conflict governance: Building a sustainable peace. In: BRUCH, C.;MUFFETT, C., et al (Ed.). Governance, Natural Resources, and Post-Conflict Peacebuilding. Oxon: Routledge, 2016.

COLLIER, P. Development and Conflict. Center for Study of African Economies, Department of Economics, Oxford University.2004.

COLLIER, P. The Bottom Billion. Oxford University Press, 2007.

COLLIER, P.; HOEFFLER, A. Greed and Grievance in Civil War. World Bank Development Research Group. 2000.

COLLIER, P.; HOEFFLER, A.; ELLIOT, L.; HEGRE, H. et al. Breaking the conflict trap: civil war and development policy. World Bank. Washington DC. 2003.

CURTIS, M. The New Colonialism: Britain's scramble for Africa's energy and mineral resources. War on Want. London. 2016. 
DORNINGER, C.; HORNBORG, A.; ABSON, D. J.; VON WEHRDEN, H. et al. Global patters of ecologically unequal exchange: Implications for sustainability in the 21st century. Ecological Economics, 179, 2021.

DUBE, O.; VARGAS,J.F. Commodity Price Shocks and Civil Conflict: Evidence from Colombia. The Review of Economic Studies, 80, $\mathrm{n}$. 4, p. $1384-1421,2013$.

FEARON, J.D. Primary commodity exports and civil war. Journal of Conflict Resolution, 49, p. 483-507,2005.

FEARON, J.D.; LAITIN, D. Ethnicity, insurgency, and civil war. American Political Science Review, 97, n. 1, p. 75-90, 2003.

FERNANDES, S. Ecosocialism from the Margins. NACLA Report on the Americas, 52, n. 2, p. 137-143, 2020.

GFI. Financial Flows and Tax Havens: Combining to Limit the Lives of Billions of People. Global Financial Integrity.2015.

GLOBAL FINANCIAL INTEGRITY; NORWEGIAN SCHOOL OF ECONOMICS; JAWAHARLAL NEHRU UNIVERSITY; INSTITUTO DE ESTUDOS SOCIOECONÔMICOS et al. Financial Flows and Tax Havens: Combining to Limit the Lives of Billions. 2015.

GLOBAL WITNESS. Defending Tomorrow: The climate crisis and threats against land and en vironmental defenders. 2020.

GOOD LIFE FOR ALL PROJECT. A Good Life For All Within Planetary Boundaries. 2018. Disponível em: https://goodlife.leeds.ac.uk/countries/\#Vietnam. Acesso em: 5th of April.

HALLIDAY, F. Rethinking International Relations. London: Palgrave, 1994.

HARVEY, D. The New Imperialism. Oxford: Oxford University Press, 2005.

HICKEL,J. The Divide: A Brief Gide to Global Inequality and its Solutions. 2018 ed. London: Windmill Books, 2017.

HICKEL, J. Quantifying national responsibility for climate breakdown: an equity-based attribution approach for carbon dioxide emissions in excess of the planetary boundary. Lancet Planet Health, 4, p. e399-404,2020.

HICKEL, J.; SULLIVAN, D.; ZOOMKAWALA, H. Plunder in the Post-Colonial Era: Quantifying Drain from the Global South Through Unequal Exchange, 1960-2018. New Political Economy, 2021.

HUMPHREYS, M. Natural Resources, Conflict and Conflict Resolution: Uncovering Mechanisms. The Journal of Conflict Resolution, 49 , n. 4, p. 508-537,2005.

ICMM. Role of mining in national economies: Mining Contribution Index. International Council on Mining \& Metals. 2016.

IPCC. Third Assessment Report: Climate Change 2001: Working Group 2: Impacts, Adaptation and Vulnerability. International Panel on Climate Change. Cambridge. 2001.

JOHNSON, M. Strong Institutions in Weak States: Institution Building, Natural Resource Governance, and Conflict in Ghana and Sierra Leone. 2017. (PhD) - Environmental Policy, Duke University, Durham, NC.

KALLIS, G. Degrowth. Agenda Publishing. Newcastle upon Tyne, United Kingdom. 2018.

KOTHARI, A.; DEMARIA, F.; ACOSTA, A. Buen vivir, Degrowth and Ecological Swaraj: Alternatives to sustainable development and the Green Economy. Development, 57, p. 362-375, 2014.

KOUBI, V. Climate Change and Conflict. Annual Review of Political Science, 22, n. 1, p. 343-360, 2019.

KRENAK, A. Ideias para adiar o fim do mundo. São Paulo: Companhia das Letras, 2020.

LANG, M. Alternativas ao desenvolvimento. In: DILGER, G.;LANG, M., et al (Ed.). Descolonizar o imaginário: debates sobre pósextrativismo e alternativas ao desenvolvimento. São Paulo: Autonomia Literária \& Editora Elefante, 2016.

LE BILLON, P.; LUJALA, P. Environmental and land defenders: Global patterns and determinants of repression. Global Environmental Change, 65 , p. 1-16, 2020.

LUXEMBURG, R. The Accumulation of Capital. 1971 ed. London: Routledge and Kegan Paul, 1913.

MURPHY, R. Accounting for the Missing Billions. In: REUTER, P. (Ed.). Draining Development? Controlling Flows of Illicit Funds from Developing Countries. Washington, DC: World Bank, 2012

O’NEILL, D.; FANNING, A. L.; LAMB, W. F.; STEINBERGER, J. K. A good life for all within planetary boundaries. Nature Sustainability, 1, p. 88-95, 2018.

PELUSO, N.; WATTS, M. Violent Environments. Ithaca: Cornell University Press, 2001.

PETRIDIS, P.; MURACA, B.; KALLIS, G.Degrowth: between a scientific concept and a slogan for a social movement. In: MARTÍNEZ-ALIER, J. e MURADIAN, R. (Ed.). Handbook of Ecological Economics. Cheltenham, UK \& Northhampton, USA: Edward Elgar Publishing, 2015. 
PRADO, F. C. A ideologia do desenvolvimento e a controvérsia da dependência no Brasil contemporâneo. Marília: Lutas Anticapital, 2020.

PUENTE, R. “Vivir bien” y descolonización. In:FARAH, I. e VASAPOLLO, L. (Ed.). Vivir bien: ¿Paradigma no capitalista? .La Paz: CIDESUMSA, 2011.

RESTREPO BOTERO, D. I.; PEÑA GALEANO, C. A. Territories in Dispute: Tensions between 'Extractivism', Ethnic Rights, Local Governments and the Environment in Bolivia, Colombia, Ecuador and Peru. In: CARBONNIER, G.;CAMPODÓNICO, H., et al (Ed.). Alternative Pathways to Sustainable Development: lessons from Latin America. Geneva, Boston: Graduate Institute Publications, Brill-Nijhoff, 2017.

RODNEY, W. How Europe Underdeveloped Africa. London: Bogle-L'Ouverture Publications, 1972.

ROE, A.; DODD, S. Dependence on extractive industries in lower-income countries: the statistical tendencies. WIDER Working Paper, No 2017/98. : The United Nations University \& World Institute for Development Economics Research 2017.

ROSS, M. L. How do Natural Resources Influence Civil War? Evidence from Thirteen Cases. International Organization, 58, n. 1, p. 35$67,2004 \mathrm{a}$.

ROSS, M. L. What do we know about natural resources and civil war? Journal of Peace Research, 41, n. 3, p. 337-356, 2004b.

ROSTOW, W. W. The Stages of Economic Growth: A Non-Communist Manifesto. 3rd ed. Cambridge: Cambridge University Press, 1960.

ROTHSTEIN, B.; VARRAICH, A. Making Sense of Corruption. Cambridge University Press, 2017.

SACHS, J. D. The End of Poverty: How We Can Make It Happen in Our Lifetime. Penguin Books, 2005.

SAJED, A. From the Third World to the Global South. : E-International Relations. 20212020.

SDI. Sustainable Development Index. 2019. Disponível em: www.sustainabledevelopmentindex.org Acesso em:5th of April.

SMITH, J. Imperialism in the Twenty-First Century: The Globalization of Production, Super-Exploitation and the Crisis of Capitalism. New York: Monthly Review Press, 2016.

SOLÓN, P. Bem Viver. In: SOLÓN, P. (Ed.). Alternativas sistêmicas: Bem Viver, decrescimento, comuns, ecofeminismo, direitos da Mãe Terra e desglobalização. São Paulo: Editora Elefante, 2019.

STAVRIANOS, L. S. Global Rift: The Third World Comes of Age. William Morrow \& Co, 1981.

SVAMPA, M. Extrativismo neodesenvolvimentista e movimentos sociais: um giro ecoterritorial rumo a novas alternativas? In:DILGER, G.;LANG, M., et al (Ed.). Descolonizar o imaginário: debates sobre pós-extrativismo e alternativas ao desenvolvimento. São Paulo: Autonomia Literária \& Editora Elefante, 2016.

TEMPER, L.; DEL BENE, D.; MARTINEZ-ALIER, J. Mapping the frontiers and front lines of global environmental justice: the EJAtlas. Journal of POlitical Ecology, 22, n. 1, 2015.

WEGENAST, T.; SCHNEIDER, G. Ownership matters: Natural resources property rights and social conflict in Sub-Saharan Africa. Political Geography, 61, p. 110-122, 2017. 